\title{
Aesthetic Value, Artistic Value, and
}

\section{Morality}

\section{[Penultimate Version]}

For citation and reference, please see the definitive and final version forthcoming in David Coady, Kimberley Brownlee, and Kasper Lipper-Rasmussen (eds.) Blackwell Companion to Applied Philosophy (Blackwell, forthcoming).

This entry surveys issues at the intersection of art and morality. Particular emphasis is placed on whether, and in what way, the moral character of a work of art influences its artistic value. Other topics include the educational function of art and artistic censorship.

Aesthetic Value; Artistic Value; Value of Art; Artistic Judgment; Moral Character; Cognitive Value; Ethical Criticism; Artistic Acts; Moral Education; Censorship.

Andrea Sauchelli is an Assistant Professor in the Department of Philosophy at Lingnan University, Hong Kong. 
In his entry 'Genève' for the Encyclopédie (1757), Jean Le Rond d'Alembert reported that the Swiss city, at that time, did not have a theatre. He also claimed that the main problem related to the establishment of a theatre would not be with the content of theatrical representations but rather the presence of actors - people who could spread amongst the youth loose morals and an unnecessary taste for adornment. Despite these problems, D'Alembert argued that the genevois could certainly find some regulations to avoid these downsides and profit from the benefits provided by a theatre, such as an improvement to both the morals and tact of the population. JeanJacques Rousseau vehemently replied to these suggestions (Rousseau 1960). In particular, one of Rousseau's arguments against the establishment of a theatre in Geneva was his view of what constitutes theatrical success: an (excessive) arousal of emotions to the detriment of moral reasoning and true moral education. Rousseau supported his claim by analyzing what he regarded as the most perfect of the French theatrical representations of the time, Molière's Le Misanthrope (1666). Rousseau complained that in this satirical comedy of manners, a virtuous man, the protagonist Alceste, is represented as ridiculous because of his moral stubbornness and apparently inappropriate display of honesty in social contexts. Rousseau maintained that deprived of its immorality — the act of representing a person committed to honesty and virtue as appearing, in certain cases, socially inept - the play would not have been artistically successful (Rousseau 1960, 47). A related point made by Rousseau was that a play cannot provide any moral 'healing' or spiritual relief because a successful sample of this form of art aims at stirring up emotions, while only through reason can negative moral sentiments be healed. True virtue has no place on the stage: a virtuous Stoic would bore us or look ridiculous, as does Alceste in Le Misanthrope. So, given that (successful) plays cannot teach anything morally good because their way of educating is intrinsically wrong and may likely have immoral effects, Rousseau claimed that a theatre would only obstruct those other healthy and peaceful activities that were already the source of pleasure and spiritual relief for the citizens of Geneva. 
Leaving aside the interpretative demerits of Rousseau's reading of Le Misanthrope, his discussion on the relationship between art, in this case the art of theatre, and morality is just one of the many instances of a long debate that has had far-reaching consequences for fields ranging from art criticism to legal theory. In this entry, I focus only on a selection of the various questions that have recently interested aestheticians and philosophers of art. More specifically, I provide the theoretical tools and starting points to invite the reader to take up questions such as the following: can works of art be immoral? Is it always the case that the alleged immorality of a work of art constitutes an artistic or aesthetic defect? What general reasons can be given to limit the freedom of artistic expression?

Particular emphasis is placed on the debate on whether and how the moral value of a work of art influences its artistic value. After introducing the main families of theories on the relationship between the artistic, aesthetic and moral values of works of art, I discuss a few varieties of interactionism and provide arguments to evaluate the debate between ethicism and contextualism (two varieties of interactionism). A crucial aspect of the debate is the cognitivist claim, the main idea of which is that art, in at least certain cases, can have cognitive value because it conveys either propositional or other forms of knowledge. The issue of censorship is then discussed with reference to three general reasons given to limit artistic expression, two consequentialist and one deontological.

\section{Aesthetic, Artistic, and Moral Values}

\subsection{Value(s) of Art}

Following Robert Stecker (and many others), I take it for granted here that there are different types of value, among them also composite ones (Stecker 2005a and 2005b). The artistic value of a work can be defined as a composite or an aggregation of its aesthetic, cognitive, and, possibly, historical values. On this view, the artistic value 
of a work of art is thus influenced, but not entirely determined, by its aesthetic value. Morality can influence the artistic value of a work in different ways; for instance, its moral value can be part of its cognitive value and/or also influence its aesthetic value - if we also assume certain controversial theories according to which what is morally good is also thereby aesthetically valuable or, in a certain sense, perceptually pleasing (see Norton 1995). In the current debate, it is not always specified whether the moral value of a work of art contributes to its artistic or aesthetic values separately, or only to one, or to both simultaneously. Certain authors, such as Berys Gaut, argue that the realm of the aesthetic and that of the artistic are one and the same (Gaut 2007). The reasons behind this identification are mainly variations on the idea that a tenable distinction between the two types of value - artistic and aesthetic - has not yet been provided. However, I think that a useful distinction between artistic and aesthetic values can be drawn. One of the main reasons for this distinction is that, in contemporary art criticism, certain works are considered good art despite their lack of some of the properties that are traditionally taken be aesthetically positive (i.e., beauty, harmony, balance, and so on). In addition, some contemporary works of artcertain installations, works of conceptual art, experimental video art projects, etc.are considered as such (and even successful) not by virtue of their aesthetic properties; in many cases, the main contribution of such works to the art world is not their perceived aesthetic merit (see Goldman 1995). The point is that although contemporary works of art have aesthetic properties, their possession of, for example, beauty is not taken by their authors or art critics to be what is relevant for their artistic evaluation (see Goldie \& Schellekens 2009). Additionally, the artistic value of a work is sometimes taken to have at least another component, namely, its cognitive value, which does not seem to be easily classified as aesthetic.

\subsection{Interactionism and Autonomism}

The view according to which the moral value of a work of art influences, in ways to be specified, its aesthetic or artistic values (and vice versa) is called 'interactionism'. 
Interactionist views include ethicism and contextualism. According to ethicism, a moral flaw in a work of art is always also an artistic or aesthetic defect. According to contextualism, the relationship between the moral value of a work of art and its artistic or aesthetic values is not systematic in the sense that the following can be true: there are artistic contexts (genres, categories of art, etc.) in which a moral defect in a work of art constitutes an aesthetic or artistic merit. On the other hand, ethicists maintain that the connection between moral and artistic (and/or aesthetic) values is systematic - to a positive increase of the relevant moral value of a work there always corresponds a positive increase in (at least) its artistic or aesthetic values; an analogous generalization holds for decreases in moral value. How these interactions between different types of values take place is a matter of significant controversy. For instance, Antony Aumann has recently claimed that the aesthetic value of a work can also positively or negatively affect its cognitive value (Aumann 2014). The examples he gives are certain philosophical works that have been praised for their literary qualities - Nietzsche's Genealogy of Morals, Plato's Republic, etc.- - but also, and for different reasons, certain papers and essays in the contemporary analytic style. Given the considerable number of ways in which values may affect each other, interactionist views should include a specification of the various relations of influence between the values at issue: there can be philosophically tenable positions to the effect that, in certain cases, having aesthetic defects may diminish the cognitive and thus the artistic value of a work. Many other combinations are logically possible. However, in what follows I focus solely on those positions that have been currently advocated in the literature.

The other family of theories discussed here, 'autonomism', defends the idea that the moral or cognitive values of a work of art do not influence its aesthetic value or its artistic value. There can be mixed views, which we may call partial autonomisms or partial interactionists. For example, there can be theories according to which there is a contextual correlation between the artistic and moral values of a work of art, while the moral value and aesthetic values are independent from each other. Despite the 
many possible permutations, I again discuss only those views that have been actually defended. Another preliminary question must be addressed: how can a work of art, in many cases an inanimate object, be the object of a moral evaluation or have moral value at all?

\subsection{The Moral Character of Artworks}

There are many ways of making sense of attributions of moral properties to an artwork. For example, Gaut, drawing on the work of Guy Sircello, suggests that moral judgments concerning works of art should be understood as judgments concerning what the author(s) performs or does through his/her works ((Gaut 2007, 71-3) and (Sircello 1972)). The object of moral appraisal is what a number of agents (the number varies in relation to the number of authors or people responsible for the production of the work) has done through an object. In other words, the moral character of a work is given by an evaluation of the artistic act performed through it, where the artistic act is a type of action performed by rational agents - which can be collective in case there is more than one author. In this regard, the recognition of the intentions of the authors of a work can be important for determining the moral character of a work; Gaut claims that even when a work seems to be immoral because it contains certain immoral claims or representations, the moral character of the work should be judged on the basis of the effect that the authors intend to achieve by using their artistic skills (more on this in the section on ethicism). Possible alternatives involve judging the direct (or expected, foreseeable, etc.) consequences of the act in question, depending on the preferred normative ethical theory. For instance, the moral character of a work of art can be judged on the basis of the type of prescriptions or points of view implied or suggested rather than only on what it is explicitly arguing for. In addition, a work of art can be assessed morally because of its purpose or proper function (as in the case of architectural works) or by virtue of the material or process used to make it (see Sauchelli 2012b). 
The recent film The Wolf of Wall Street (Scorsese 2013), which portrays the first part of the life of a stock broker who made a fortune by swindling his clients, is an example of a morally ambiguous, and difficult to classify, work. The moral character of the movie is not clear because despite the sympathetic way in which the (seemingly) immoral protagonist is represented and the complete lack of emphasis on the point of view of his victims, there are also scenes suggesting a more moralistic take on the whole issue. It can be argued that, to show the appeal of a life of vice and financial profligacy, the film had to portray the characters in the way Scorsese did: making a movie in which driving expensive cars and travelling in fancy boats is not appealing would not have been credible. Certainly, there is some overindulgence in some scenes, but it can be replied that, in certain cases, if the effect on the audience was that of 'oh-again' at the umpteenth sex and drugs scene, this can be taken as a successful attempt at showing the (alleged) emptiness and repetitiveness of certain insipid and depraved activities. Scorsese's intention may also have been that of depicting as realistically as possible the dangerously seductive lifestyle of the people involved, given that the film is inspired by a true story. Be that as it may, if Scorsese's intention was that of depicting the dark and seductive appeal of greed and a certain lifestyle, then, if the movie is also a type of satire, the movie is most likely successful. If his intention was that of moralizing to the audience, then it is not clear whether, in this sense, his artistic act was successful: was his intention to produce a satire clear enough (and clearly perceivable by the audience) and were the artistic means he used adequate to this task? Other works are easier or less controversial to assess: Leni Riefenstahl's The Triumph of the Will is a documentary that glorifies Nazism, which I assume people should take to be immoral (along with its glorifications).

\section{Autonomism}

In the $19^{\text {th }}$ century, many artists associated with symbolism and the Decadent movement explored the idea that beauty may come from both moral or 
immoral subjects (see Bell-Villada 1996 for an account of the development of the idea of 'art for art's sake'). Contemporary autonomists, who do not always clarify whether their positions regard aesthetic or artistic values (or both), maintain that judging the aesthetic or artistic merits of a work of art by taking into account its moral character is incorrect. For instance, James Anderson and Jeffrey Dean argue that there are many cases in which our aesthetic judgments concerning a work of art are in conflict with its moral evaluation (Anderson \& Dean 1998). Richard Posner makes an even stronger claim: the moral properties of a work of literature can be mere distractions when evaluating a work aesthetically (Posner 1997). Anderson and Dean's position seems to be a form of both aesthetic and artistic autonomism; in fact, in presenting their objections against Gaut's and Carroll's views, they also claim that the moral character of an artwork never influences its value as an artwork (Anderson \& Dean 1998, 152). Anderson and Dean also tentatively propose that autonomism provides the best explanation of the numerous conflicting evaluations we make of morally contentious works of art. This idea can be articulated as an argument having the form of an inference to the best explanation: 1) there are conflicting evaluations concerning the moral character and the aesthetic value of certain artworks (i.e., Quentin Tarantino's Reservoir Dogs and Pulp Fiction are good movies, but they are immoral); and 2) the best explanation of the possibility of such a conflict is that aesthetic and moral values are distinct and do not interact. However, the argument does not seem to be persuasive, at least not before we have analyzed in detail the alternative explanations provided by the other theories discussed in the previous sections.

Autonomists also maintain that there are certain works of art, such as pure orchestral music or abstract works, which do not seem to provide an ethical point of view or have a moral character at all. The artistic autonomist may generalize this observation and claim that, if these works are supposed to have anything in common with other members of the art world, this common 
element cannot be their moral value. Thus, it is not essential for works of art to have any moral value. Therefore, if we consider the moral value of a work of art as contributing to its artistic value, we are making the mistake of considering certain criteria of evaluation that do not count in the evaluation of an object qua work of art. One of the problems with this line of reasoning seems to be its reliance on the idea that the proper function of a work of artthe element supposed to be common to all works of art-is solely that of providing a type of detached aesthetic experience. This experience is sometimes characterized as being valuable independent of its cognitive value or as being structured in a way in which our conceptual capacities are not applied in their 'normal' cognitive function. The debate on the notion of aesthetic experience and the role it plays concerning the definition of art is lengthy and controversial (see Dickie 1964), (Carroll 2012), (Iseminger 2004) and (Livingston 2004) for discussion).

Artistic or aesthetic autonomists also emphasize the idea that it is the way in which a message is conveyed that contributes to artistic success. Whether such a message is true or false does not matter from an artistic perspective. Peter Lamarque has articulated this idea in various places, in particular, in relation to literature (see (Lamarque \& Olsen 1994) and (Lamarque 2006)). More specifically, he claims that although works of art can be serious, educational and not just a formal play, when a work is evaluated as art - when its artistic value is at stake - the capacity to convey knowledge is not under consideration (Lamarque 2006, 127). The examples he uses to illustrate his case-a Schubert string quartet, a Brancusi sculpture, a Frank Lloyd Wright house, and so onare artfully picked, as few, according to Lamarque, would think that the value of these works qua works of art is related to their cognitive value, which is understood to be the capacity of the work to provide truths ((Lamarque 2006, 128). An autonomist may use this line of reasoning for arguing that the proper attitude to be adopted in judging a work of art has nothing to do with its 
cognitive value. The role played by the cognitive value of a work of art in its evaluation as art is therefore connected to the capacity of art to provide moral education. The question, then, is whether such a capacity is integral to or part of the value of a work as a work of art?

\section{Art, Cognitive Value, and Moral Education}

In the Western tradition, Plato offers a systematic discussion of the way in which the philosopher-kings should censor the artists who contribute, with their poems and stories, to the education of the youth of the city (see Janaway 1995). This presupposes the idea that art can indeed educate or have some cognitive content. The great majority of philosophers, from Aristotle to recent advocates of the value of the humanities, have maintained that works of art are either essential or highly suitable for teaching general truths, in particular, moral truths (Nussbaum 1986 and 1990), (Carroll 1998), and (Hamilton 2003). The idea that moral cultivation is connected to art is also important in the Chinese tradition; for instance, Confucius associates the practice of certain types of music with the junzi (君子, roughly translated as 'the exemplary person') (see Lai 2003 and Kim 2006).

Jerome Stolnitz famously claimed on the contrary that the types of truths that can be obtained even from great works of literature are generally trivial or overblown generalizations (Stolnitz 1992). However, not all philosophers employ the notion of truth when they go on to specify what they take to be valuable in the teachings of works of art (Carroll 1998). In particular, the cultivation approach - a cluster of ideas variously defended by Wayne Booth, Iris Murdoch, Martha Nussbaum, and Carroll, along with many other philosophers over the centuries - circumvents objections to the idea that art can provide moral education by claiming that, even if art cannot provide propositional knowledge, there are different types of knowledge and skills at 
stake in appreciating art. Among these skills, we can list the capacity for finer perceptual discrimination, imagination, emotions, and the overall ability to conduct moral reflection. Martha Nussbaum, for example, emphasizes the capacity of certain novels - for instance, those of Henry James - to direct our attention to the particular lives of distinct (fictional) individuals and thereby stimulate our capacity to imaginatively take up the specific conditions of other people (Nussbaum 1990). Such a capacity, sometimes called recreative imagination, is assumed to be of central importance for morality (see Currie \& Ravenscroft 2004). Nonetheless, some have noted that an increasing sensitivity and imagination do not necessarily lead to morally good behavior (Hamilton 2003). For instance, an imaginative individual can grow better at hurting people.

\section{Ethicism}

According to artistic ethicism, the moral value of a work of art, when relevant to its artistic evaluation, is systematically connected to its artistic value. The nature of this connection between the types of value at issue is systematic in the sense that every moral defect that is relevant to the artistic evaluation of a work thereby decreases the artistic value of the work at issue. Similarly, a moral merit, when relevant, increases the artistic value of the work. Ethicists do not claim that having moral value, in itself, makes a work a great work of art: it is not enough to contain or to have a positive moral character for a work to also be a masterpiece or a great example of its genre. Having a bad moral character is also not sufficient for being an artistic disaster: a work of art may be a good example of its type despite its immorality. Aesthetic ethicism can be similarly explicated, with the exception that, instead of referring to the artistic value of a work, the view simply claims that moral defects (or merits) decrease (or increase) the aesthetic value of a work. 
Why should we believe these theories? One argument in favor of artistic ethicism is the so-called merited response argument, the origin of which has been claimed to be David Hume's essay 'Of the Standard of Taste'. Gaut's version of the argument relies on the idea that, every time that a work of art prescribes an unmerited response, the work thereby has an artistic defect (Gaut 2007). Sauchelli reconstructs the merited response argument with respect to artistic ethicism as follows (Sauchelli 2013):

1. The attitude that a work manifests can constitute an ethical defect;

2. An artwork's attitude is typically manifested in prescribing certain responses to the events represented in the work;

3. There are unmerited responses, for instance, when these responses are unethical;

4. Unmerited prescribed responses that are unmerited because they are unethical constitute artistic defects of the artwork;

5. Hence, an artwork's manifestation of ethically bad attitudes in the work's prescribed responses is an aesthetic/artistic defect.

Premise 4 is supported by the idea that the responses that the artwork prescribes are artistically relevant, which, in turn, is supported by the previously discussed criterion of artistic relevance.

Certain philosophers have argued that one of the theses generally accepted by many interactionists - the cognitivist claim — creates a problem at the heart of artistic ethicism. Matthew Kieran's line of reasoning in support of this criticism can be summarized as follows (Kieran 2003). Some works of art prescribe us to assume an immoral point of view, for example, the point of view of a pedophile, or they prescribe us certain attitudes toward immoral fictional or nonfictional (i.e., real) situations. The full appreciation of such works involves the adoption of an immoral point of view and/or an immoral attitude; art can have cognitive value, and part of what it can teach also includes moral truths, skills, etc. If part of the artistic value of an artwork is the cognitive gain we can obtain by engaging with the work in question, 
and such cognitive gain requires a certain degree of immorality on the part of the work, then the work may have cognitive value by virtue of its immoral character because by engaging with the work in question, the (temporary) adoption of an immoral point of view (and of apparently immoral attitudes to certain events or persons) broadens our moral skills. Ethicism seems to imply that a prescription of an immoral attitude is always an artistic defect, given that this is one way in which a work can be immoral. However, this argument contradicts what has been previously suggested, namely, that prescribing immoral attitudes can bring about cognitive gain (and thus artistic merit). Gaut (2007) provides the following reply to the previous argument:

1. A proper description of an act of teaching requires that the teacher must transmit truths intentionally. (This condition is meant to exclude cases in which, by making a mistake, an agent that happens to be an unintentional source of knowledge is taken as teaching something.)

2. Many of those works classified as immoral are not actually aimed at convincing the audience to become immoral. After all, these works aim to teach moral truths even when they prescribe immoral attitudes to achieve this aim.

3. If an artistic act aims at teaching a moral truth by prescribing an immoral attitude, the artwork is not immoral by virtue of this prescription. If the work does not contain any moral truth, the work cannot teach anything. In this last case, if we do learn something from it, it is only a side effect of our appreciation of the work.

4. Thus, ethicism is not harmed by Kieran's objection: we cannot obtain moral cognitive gain from properly classified immoral artworks.

The argument relies on the idea that when an immoral perspective is prescribed, either a related cognitive gain is obtained despite this prescription, and thus is not an aspect to be valued in the artwork itself, or the cognitive gain is not something the merit of which should be attributed to the work in question because the work does not 
contain anything that can be learned (see Sauchelli 2012a for a series of objections to the previous argument).

\section{Contextualism}

Few contemporary philosophers would hold, similar to Rousseau, that a necessary requirement to be valuable qua work of art is to be immoral. A far more popular family of theories is artistic contextualism, the main point of which is that the connection between artistic value and moral value, when present and relevant, is not systematic in the sense that it is not always true that a work having a defective moral character is thereby less valuable as a work of art. This last claim does not rule out the possibility that certain works are so morally repulsive that their immorality constitutes an aesthetic or artistic switch off (see Sauchelli 2012b).

There is at least one understanding of the scope of the 'systematicity' regarding the connection between moral and artistic values that would result in artistic contextualism's compatibility with the idea that there are 'systematic', in the sense of stable or constant, connections between artistic and moral values; for instance, we may argue that there are certain artistic categories that always prescribe certain criteria of success to the effect that works of art belonging to these categories must have an immoral character. Given the existence of immoral artistic categories-Nazi propaganda, animal exploitation films, etc.- - some of the works that belong to those categories must be immoral to be artistically valuable (or better), that is, to be good examples of their type. There may also be forms of contextualism according to which 1) the evaluation of the artistic or aesthetic value of certain works sometimes requires us to take into account moral considerations to the effect that sometimes an artwork can be better by virtue of its immoral character; and 2) considerations of genre are not systematic in the sense that there is not a constant connection, even within a specific genre, between artistic and aesthetic value and the moral character of a work (see (Beardsley 1958/1981, Walton 1970, Sibley 1974, and 2005, for discussion). 
One crucial assumption behind Gaut's merited response argument is that, if a work of art prescribes an immoral response (by which it is here meant either as a prescription to adopt an immoral point of view or as an immoral attitude), then the prescriptions are not merited. Sauchelli claims that it is not the case that all of the artistic categories for which moral considerations are relevant already include, as a criterion of success, that instances of such categories must have positive moral character or that they cannot have an immoral character. For instance, certain categories of abstract art or purely instrumental music do not seem to have such requirements. Thus, including the prescription of not having an immoral character seems to require a further justification to be taken as constituting a reason for considering certain responses as not merited (Sauchelli 2013, 239-46):

1. The moral character of a work of art is typically (but not exclusively) manifested in the type of prescriptions and attitudes that the work requires us to adopt to appreciate it.

2. The type of prescriptions that are merited for a work of art qua work of art is determined by the artistic category to which the work belongs.

3. There can be responses that are merited by virtue of their being immoral, if there are immoral artistic categories, and prescribing such responses can constitute an artistic merit.

4. Thus, an artwork's manifestation or prescription of immoral attitudes in the work's prescribed responses can be an artistic merit.

Sauchelli claims that an artistically relevant response is not merited in cases in which the features of a work somehow contrast with the prescription of the relevant artistic category. If we accept the idea that there are immoral artistic categories, then a merited response to a work of art that is properly categorized as an example of such a category can be merited by virtue of being immoral. The ethicist seems to have the Herculean task of showing that artistic categories do not (and perhaps cannot) include 
immoral prescriptions as criteria of artistic success in a way that does not beg the question.

\section{Art and Censorship}

Artistic acts, understood as the objects of moral appraisals, can also be viewed as instances of an artist's freedom of speech, provided a broad specification of 'speech'. More specifically, this broader understanding should be wide enough to include the production of works of art. Which artistic acts should be limited or banned in their entirety? (See West 2012 and Dwyer 2009). One condition on the scope of limitations to artistic acts can be stated as follows: free artistic expressions subject to restrictions are those intended by their authors to be communicated and shared with others. For instance, a racist novel written in an artistic form but not intended for publication and secretly kept by its author should not be punished in case of its accidental retrieval (provided the author took appropriate measures to conceal it). Unless a policy of private thought-crimes is implemented, limiting actions to artistic expressions should be directed at those artistic acts that are made (or intended to be made) publicly available. Obviously, different positions can also be adopted with respect to the domain and scope of limitations of artistic acts in relation to their public availability. For instance, someone may hold a position to the effect that artists may have the right to produce certain works, provided that they do not display them in specific public spaces or that such works are not made available to certain age groups.

One of the main reasons offered for limiting artistic expression is when a work of art is immoral. However, even if a work is immoral, it does not immediately follow that it must be censored; in fact, a disputed topic in the philosophy of law is to what extent morality should even be enforced by law (see Greenawalt 2010 and Marmor 2011), and a good case can be made that, insofar as valuable artistic means are employed to constitute a not extremely outrageous violation of public security (i.e., 
apologies of pedophilia or terrorist acts), a certain elasticity in punishing some 'outrageous' expressions should be applied.

A well-known defense of free speech is provided by John Stuart Mill in his On Liberty. No matter how immoral an artistic expression may appear to the general public, the point of view expressed by the work should be accessible. The limitation proposed by Mill to free speech is what is known as the Harm Principle, the main idea of which is that a civilized society can exercise its right to limit free speech only to prevent harm to others. Thus, in the case of works of art, a society would be justified in limiting certain artistic acts in cases in which such acts would constitute harm to others. Different cases may command different specifications of what is meant by harming others and whether a certain degree of expected harm can somehow be justified in light of the other possible goods that the artistic acts may deliver. For instance, many would agree that a work of art should be banned because of its toxicity: an installation made of radioactive material — and not displayed in the right conditions - may well be banned or destroyed.

Joel Feinberg maintains that there are cases in which we would be justified in limiting free speech when some acts constituted an offence to someone (Feinberg 1985). Applied to the case of art, the idea is that offending certain groups (or individuals) can be a sufficient reason to limit freedom of artistic speech. Although offending someone seems to be less serious than directly harming someone, the offence principle says that a certain degree of limitations to free speech is justified in the case of offence.

Consequentialist considerations may not be the sole ground for limiting certain artistic expressions. For example, Rae Langton has argued that certain restrictions to certain pornographic works are justified on the liberal premise of equal concern and respect for women (Langton 2009); to the extent that certain works portray women as entities who do not have the same equal status as citizens, restrictions can be applied. 
It must be added that the simple representation of women as not being equal citizens - or, more generally, as independent and rational moral agents — is not in itself immoral. What matters is the way in which the content is presented: if women are represented as being not equal citizens and in a way that requires the approval of such a stance toward women, then the work in question would somehow be immoral. Similarly, the idea can be applied to other social groups and the way in which they are portrayed, whether they are men, Muslims, or members of the Church of Scientology.

The possible risks of limiting artistic expressions for the above reasons are various. Among them, there is the risk of abuse, which is particularly significant because of the absolute commitment of some beliefs held by people who belong to certain religious groups. Although the case of religion is by no means the only one relevant here, some groups seem to abuse the alleged right to not feel offended or discriminated against as equal citizens, even in cases in which some of these artistically expressed criticisms may seem to be rational or at least worth considering. Given the absolute commitment that certain religious groups require, all perceived deviations from some of their principles can be taken as offensive. If all criticisms are excluded, even when expressed in an artistic way, the risk is that of fuelling an unreasonable impossibility of producing rational and accessible means of disagreement. For their claims to be taken seriously, particularly sensitive groups may be required to show that the work they want to ban represents an unmotivated attack on other people's integrity, moral character, equal status as citizens and so on.

In addition, and as a result of our previous discussion of contextualism, if it is true that certain immoral works of art can nonetheless have cognitive value, claims advanced by certain groups to censor works that display an immoral attitude toward them should be carefully considered and should not be easily accepted because even though these works may be taken to be offensive, they may nonetheless provide cognitive gain. Sometimes beauty can be worth a little offence. 
19 of 26 


\section{References}

Anderson, James and Jeffrey T. Dean. 1998. "Moderate Autonomism." British Journal of Aesthetics, 38 2: 150-66.

Aumann, Anthony. 2014. "The Relationship Between Aesthetic Value and Cognitive Value." Journal of Aesthetics and Art Criticism 72, 2: 117-27.

Beardsley, Monroe. 1958/1981. Aesthetics: Problems in the Philosophy of Criticism. Indianapolis, IN: Hackett.

Bell-Villada, Gene. 1996. Art for Art's Sake and Literary Life. Lincoln: University of Nebraska Press.

Carroll, Noël. 1998. “Art, Narrative, and Moral Understanding.” In Aesthetics and Ethics: Essays at the Intersection, edited by Jerrold Levinson, 126-60. Cambridge, UK: Cambridge University Press.

Carroll, Noël. 2012. "Recent Approaches to Aesthetic Experience.” Journal of Aesthetics and Art Criticism, 70 2: 165-177.

Currie, Gregory and Ian Ravenscroft. 2003. Recreative Minds: Imagination in Philosophy and Psychology. Oxford: Oxford University Press.

George Dickie. 1964. "The Myth of the Aesthetic Attitude." American Philosophical Quarterly, 1, 1:56-65.

Dwyer, Susan. 2009. "Censorship." In Routledge Companion to Philosophy and Film, edited by Paisley Livingston and Carl Plantinga, 29-38. London and New York: Routledge. 
Feinberg, Joel. 1985. Offense to Others: The Moral Limits of the Criminal Law. Oxford: Oxford University Press.

Gaut, Berys. 2007. Art, Emotion, and Ethics. Oxford: Oxford University.

Goldie, Peter and Schellekens, Elisabeth, eds. 2009. Who's Afraid of Conceptual Art? London: Routledge.

Goldman, Alan. 1995. Aesthetic Value. Boulder, CO: Westview Press.

Goldman, Alan. 2005. "There Are No Aesthetic Principles.” In Contemporary Debates in Aesthetics and the Philosophy of Art, edited by Matthew Kieran, 299-312. Oxford: Blackwell.

Greenawalt, Kent. 2010. "Legal Enforcement of Morality." In A Companion to Philosophy of Law and Legal Theory, 2nd Edition, edited by Dennis Patterson, 46778. Oxford: Blackwell Publishing.

Hamilton, Christopher. 2003. "Art and Moral Education.” In Art and Morality, edited by José Luis Bermúdez and Sebastian Gardner, 37-55. London and New York: Routledge.

Iseminger, Gary. 2004. The Aesthetic Function of Art. Ithaca, NY: Cornell University Press.

Janaway, Christopher. 1995. Images of Excellence: Plato's Critique of the Arts. Oxford: Oxford University Press. 
Kieran, Matthew. 2003. "Forbidden Knowledge: The Challenge of Cognitive Immoralism.” In Art and Morality, edited by José Luis Bermúdez and Sebastian Gardner, 56-73. London: Routledge.

Kim, Ha Poong. 2006. “Confucius's Aesthetic Concept of Noble Man: Beyond Moralism." Asian Philosophy, 16, 2: 111-121.

Lai, Karyn L. 2003. "Confucian Moral Cultivation : Some parallels with musical training." In The Moral Circle and the Self: Chinese and Western Approaches, edited by Kim Chong Chong, Sor-Hoon Tan \& C. L. Ten. Chicago: Open Court Publishing.

Lamarque, Peter and Stein H. Olsen. 1994. Truth, Fiction, and Literature. Oxford: Clarendon Press.

Lamarque, Peter. 2005. "Cognitive Values in the Arts: Marking the Boundaries." In Contemporary Debates in Aesthetics and the Philosophy of Art, edited by Matthew Kieran, 127-39. Oxford: Blackwell.

Langton, Rae. 2009. Sexual Solipsism: Philosophical Essays on Pornography and Objectification. Oxford: Oxford University Press.

Livingston, Paisley. 2004. "C. I. Lewis and the Outlines of Aesthetic Experience." British Journal of Aesthetics, 44, 4: 378-392.

Marmor, Andrei. 2011. Philosophy of Law. Princeton: Princeton University Press.

Norton, Robert Edward. 1995. The Beautiful Soul: Aesthetic Morality in the Eighteenth Century. Ithaca, NY: Cornell University Press. 
Nussbaum, Martha. 1986. The Fragility of Goodness. Cambridge: Cambridge University Press.

Nussbaum, Martha. 1990. Love's Knowledge. Oxford: Oxford University Press.

Posner, Richard. 1997. "Against Ethical Criticism." Philosophy and Literature, 21, 1: $1-27$.

Rousseau, Jean Jacques. 1960. Politics and the Arts, Translated by Allan Bloom. Ithaca, New York: Cornell University Press.

Sauchelli, Andrea. 2012a. "Ethicism and Immoral Cognitivism: Gaut vs. Kieran on Art and Morality." Journal of Aesthetic Education, 46, 3: 107-118.

Sauchelli, Andrea. 2012b. "Functional Beauty, Architecture, and Morality." The Philosophical Quarterly, 62, 246: 128-147.

Sauchelli, Andrea. 2013. "The Merited Response Argument and Artistic Categories." Journal of Aesthetics and Art Criticism, 71, 3: 239-246.

Sibley, Frank. 1974. "Particularity, Art and Evaluation." Proceedings of the Aristotelian Society, 48: 1-21.

Sircello, Guy. 1972. Mind \& Art. Princeton: Princeton University Press.

Stecker, Robert. 2005a. "The Interaction of Ethical and Aesthetic Value." British Journal of Aesthetics, 45, 2: 138-50.

Stecker, Robert. 2005b. "Value in Art." In The Oxford Handbook of Aesthetics, edited by Jerrold Levinson. Oxford: Oxford University Press. 
Stolnitz, Jerome. 1992. "On the Cognitive Triviality of Art.” British Journal of Aesthetics, 32, 3: 191-200.

Walton, Kendall. 1970. "Categories of Art." Philosophical Review, 79: 334-67

West, Caroline. 2012. "Pornography and Censorship." Stanford Encyclopedia of Philosophy http://plato.stanford.edu/entries/pornography-censorship/ 


\section{Further Readings}

Bermudez, Jose Luis, and Sebastian Gardner, eds. 2003. Art and Morality. London and New York: Routledge.

Boldrick, Stacy, Leslie Brubaker, and Richard S. Clay, eds. 2013. Striking Images, Iconoclasms Past and Present. Ashgate Publishing Limited.

Cashell, Kieran. 2009. Aftershock: The Ethics of Contemporary Transgressive Art. I. B. Tauris.

Devereaux, Mary. 1993. "Protected Space: Politics, Censorship, and the Arts." Journal of Aesthetics and Art Criticism 51, 2: 207-215.

Gaut, Berys. 2005. "Art and Ethics." In The Routledge Companion to Aesthetics. $2^{\text {nd }}$ Edition, edited by Berys Gaut and Dominic McIver Lopes, 431-44. London and New York: Routledge.

Hagberg, Garry, ed. 2008. Art and Ethical Criticism. Oxford: Blackwell Publishing.

Alessandro Giovannelli, 'The Ethical Criticism of Art: A New Mapping of the Territory', Philosophia, 35 (2007), pp. 117-27.

Jacobson, Daniel. 2005. "Ethical Criticism and the Vice of Moderation." In Contemporary Debates in Aesthetics and the Philosophy of Art, edited by Matthew Kieran. Oxford: Blackwell.

Kieran, Matthew. 2003. "Art and Morality." In The Oxford Handbook of Aesthetics. Edited by Jerrold Levinson, 451-70. Oxford: Oxford University Press. 
Levinson, Jerrold, ed. 1998. Aesthetics and Ethics. Essays at the Intersection. Cambridge: Cambridge University Press.

Saito, Yuriko. 2007. "The Moral Dimension of Japanese Aesthetics.” Journal of Aesthetics and Art Criticism, 65, 1: 85-97. 